\title{
Geographic Distribution and Genetic Diversity of Three Ophiosphaerella Species that Cause Spring Dead Spot of Bermudagrass
}

\author{
Henry C. Wetzel III, Department of Plant Pathology, Kansas State University, Manhattan 66506; Daniel Z. Skin- \\ ner, USDA/ARS, Department of Agronomy, Kansas State University, Manhattan 66506; and Ned A. Tisserat, De- \\ partment of Plant Pathology, Kansas State University, Manhattan 66506
}

\begin{abstract}
Wetzel, H. C., III, Skinner, D. Z., and Tisserat, N. A. 1999. Geographic distribution and genetic diversity of three Ophiosphaerella species that cause spring dead spot of bermudagrass. Plant Dis. 83:1160-1166.

The distribution of three Ophiosphaerella spp. that cause spring dead spot (SDS) of bermudagrass was studied by systematically sampling two golf courses in Oklahoma and one in Kansas. $O$. herpotricha was isolated from all three locations and was the most abundant species. It was the only SDS pathogen found at Jenks, Oklahoma. O. korrae was isolated from Afton, Oklahoma, and Independence, Kansas, whereas $O$. narmari was only detected in samples from Afton. This is the first report of all three Ophiosphaerella species on bermudagrass at the same location. Amplified fragment length polymorphism (AFLP) marker analysis was used to investigate inter- and intraspecific genetic diversity of Ophiosphaerella isolates from North America and Australia. A majority of the $O$. herpotricha and $O$. narmari isolates from Afton were distinct haplotypes, suggesting that sexual recombination was occurring within the population. Conversely, the presence of multiple isolates of $O$. herpotricha and $O$. narmari with the same haplotype also indicated that asexual propagation was occurring. The genetic diversity among $O$. herpotricha isolates from Afton was not distinctly different from that of isolates collected throughout the southern United States. In contrast, $O$. narmari isolates from Afton were distinct from those collected in Australia. The genetic diversity in $O$. korrae was markedly different than that in the other Ophiosphaerella spp. The population at Afton was dominated by just a few haplotypes, and these were nearly identical to isolates collected from bermudagrass and Kentucky bluegrass throughout western, central, and northern North America. However, $O$. korrae isolates collected in the southeastern United States were only distantly similar to other North American isolates.
\end{abstract}

Additional keywords: Leptosphaeria korrae, L. narmari

Spring dead spot (SDS) is a disease of bermudagrass (Cynodon dactylon) and bermudagrass hybrids $(C$. dactylon $\times C$. transvaalensis) in Australia $(7,23,28)$ and the United States $(3,5,9,26)$. Sunken, circular dead patches develop within the turfgrass stand as bermudagrass breaks winter dormancy. The patches are generally well-defined and range in size from a few centimeters to $0.5 \mathrm{~m}$ or more in diameter (5).

SDS is caused by the three ectotrophic root-infecting fungi Ophiosphaerella narmari (J. Walker \& A.M. Smith) Wetzel, Hulbert, \& Tisserat (=Leptosphaeria narmari J. Walker \& A.M. Smith), O. herpotricha (Fr.:Fr.) J. Walker, and $O$. korrae (J. Walker \& A.M. Smith) R.A. Shoemaker

Corresponding author: N. A. Tisserat
E-mail: tissne@plantpath.ksu.edu

Contribution of the Kansas Agricultural Experiment Station 99-394-J.

Accepted for publication 6 September 1999.

Publication no. D-1999-1018-02R

(C) 1999 The American Phytopathological Society
\& C.E. Babcock $(=$ L. korrae J. Walker \& A.M. Smith). These fungi can be differentiated on the basis of their ascospore morphology $(21,27)$, but ascocarps rarely are seen in nature and cannot be easily induced in certain isolates (2). More recently, these species have been differentiated on the basis of selective PCR amplification with species-specific primers derived from the ITS regions of the rDNA $(16,25,32)$.

Limited information is available on the geographic distribution of SDS pathogens. $O$. korrae has been documented as the cause of SDS in Maryland (3), California (5), and Australia (28). It also causes necrotic ring spot (NRS) disease of Kentucky bluegrass (Poa pratensis), annual bluegrass $(P$. апnиa), and creeping red fescue (Festuca rubra) $(4,12,33)$. NRS is limited primarily to the northern United States and Canada (19). O. narmari causes SDS in Australia (28) and New Zealand (9) and has recently been reported in the United States (32). O. herpotricha is a cause of SDS in Kansas, Oklahoma, and other areas of the United States (26), but it has not been reported on bermudagrass in Australia. Because these reports were based on relatively few isolations at each location, the true distribution of these fungi remains ambiguous.

Wetzel et al. (32) demonstrated that the three SDS pathogens clustered into a monophyletic group distinct from other tested Leptosphaeria and Phaeosphaeria species based on nucleotide sequence comparisons of the ITS regions of the rDNA. These results supported the taxonomic transfer of $L$. korrae to $O$. korrae proposed by Shoemaker and Babcock (21) and the assignment of $L$. narmari to $O$. narmari.

Less is known about the intraspecific diversity in these three SDS pathogens. Based on random amplified polymorphic DNA (RAPD) analysis, Raffle and Hsiang (19) reported a relatively low level of genotypic diversity among isolates of $O$. korrae collected from Canada and the state of Washington. They hypothesized that low numbers of genotypes were introduced into these regions, possibly on contaminated sod, and then were dispersed asexually as mycelia or by ascospores of selfed isolates. In contrast, preliminary surveys in Oklahoma and Kansas suggested a higher level of genotypic diversity among $O$. herpotricha isolates $(14,31)$.

The objectives of our research were to examine the distribution and genetic diversity of the three SDS pathogens collected from systematically sampled bermudagrass golf course fairways in Kansas and Oklahoma. The genetic diversity observed on a local and regional level was then compared with Ophiosphaerella isolates collected throughout North America and Australia.

\section{MATERIALS AND METHODS}

Fungal isolates. We systematically sampled SDS-affected bermudagrass golf course fairways at three locations (ShangriLa Resort in Afton, Oklahoma, South Lakes Golf Club in Jenks, Oklahoma, and Independence Country Club in Independence, Kansas) in May 1994 to assess the distribution and genetic diversity of SDS pathogens. The sampling pattern consisted of delineating two to three equally spaced, 6-m-radius circles on each of three fairways at the Afton and Jenks locations and two fairways at the Independence golf course. An 11-cm-diameter $\times 10.2-\mathrm{cm}-$ deep turfgrass core was removed from the margin of each of 20 SDS patches in each circle. Most SDS patches were less than 40 
$\mathrm{cm}$ diameter. An additional 10 SDS patches were randomly sampled outside the circles on each fairway. Two fairways on the Afton course were resampled in May 1996 by removing cores from 100 SDS patches at approximate 5-m intervals along a W-shaped transect.

Turfgrass cores were washed with water to remove soil from roots. Root segments, 5 to $10 \mathrm{~mm}$ long and colonized with ectotrophic hyphae, were surface-sterilized in $0.5 \% \mathrm{NaOCl}$ for $5 \mathrm{~min}$ and blotted dry on paper towels. Five segments from each soil core were placed on quarter-strength potato dextrose agar (PDA; Difco, Detroit, MI) amended with $100 \mathrm{mg}$ each of streptomycin sulfate and chloramphenicol per liter and incubated at room temperature (22 to $26^{\circ} \mathrm{C}$ ) for approximately 7 days. Putative SDS pathogens initially were selected based on morphological growth characteristics $(26,28,30)$. In most cases, a single isolate from each core was maintained on a PDA slant at $4^{\circ} \mathrm{C}$ for further testing. However, two to five isolates were collected from 50 of the 200 cores sampled in 1996 to detect potential diversity of SDS pathogens within individual patches.

We also collected or obtained $61 O$. herpotricha and $15 O$. narmari isolates from bermudagrass, and 660 . korrae isolates from bermudagrass and Kentucky bluegrass, from various regions and sources in the United States and Australia to assess their genetic diversity on a larger geographic scale. Isolation and maintenance procedures were similar to those previously described.

DNA isolation. Fungal isolates were grown in modified yeast extract broth, and DNA was extracted and resuspended for amplification in polymerase chain reaction (PCR) assays as described by Wetzel et al. (32). Oligonucleotide primers specific for $O$. herpotricha, $O$. korrae, and $O$. narmari $(25,32)$ were used to verify the identity of all SDS isolates. PCR conditions and species-specific primer sequences are described elsewhere $(25,32)$.
AFLP analysis. Amplified fragment length polymorphism (AFLP) assays were performed with AFLP Analysis System II (Life Technologies, Inc., Gaithersburg, MD). Fungal isolate template DNA was prepared in a one-step restriction-ligation reaction. Fungal genomic DNA (100 ng in $5 \mu \mathrm{l}$ of $\mathrm{dH}_{2} \mathrm{O}$ ) was digested at $37^{\circ} \mathrm{C}$ for $2 \mathrm{~h}$ with $4 \mathrm{U}$ of EcoRI and $1.6 \mathrm{U}$ of $M s e \mathrm{I}$ in $1.0 \mu \mathrm{l}$ of acetate buffer $(10 \mathrm{mM}$ Tris-acetate, $\mathrm{pH} \mathrm{7.5,} 10 \mathrm{mM} \mathrm{Mg-acetate,} \mathrm{and} 50$ $\mathrm{mM} \mathrm{K}$-acetate) in a final reaction brought to a volume of $10 \mu \mathrm{l}$ with $\mathrm{dH}_{2} \mathrm{O}$. Then, a 10- $\mu \mathrm{l}$ solution containing $0.4 \mu \mathrm{l}$ each of 5 $\mathrm{pmol} / \mu \mathrm{l} E c o$ RI-adapters and $50 \mathrm{pmol} / \mu \mathrm{l}$ of MseI-adapters, $80 \mathrm{U}$ of T4 DNA ligase
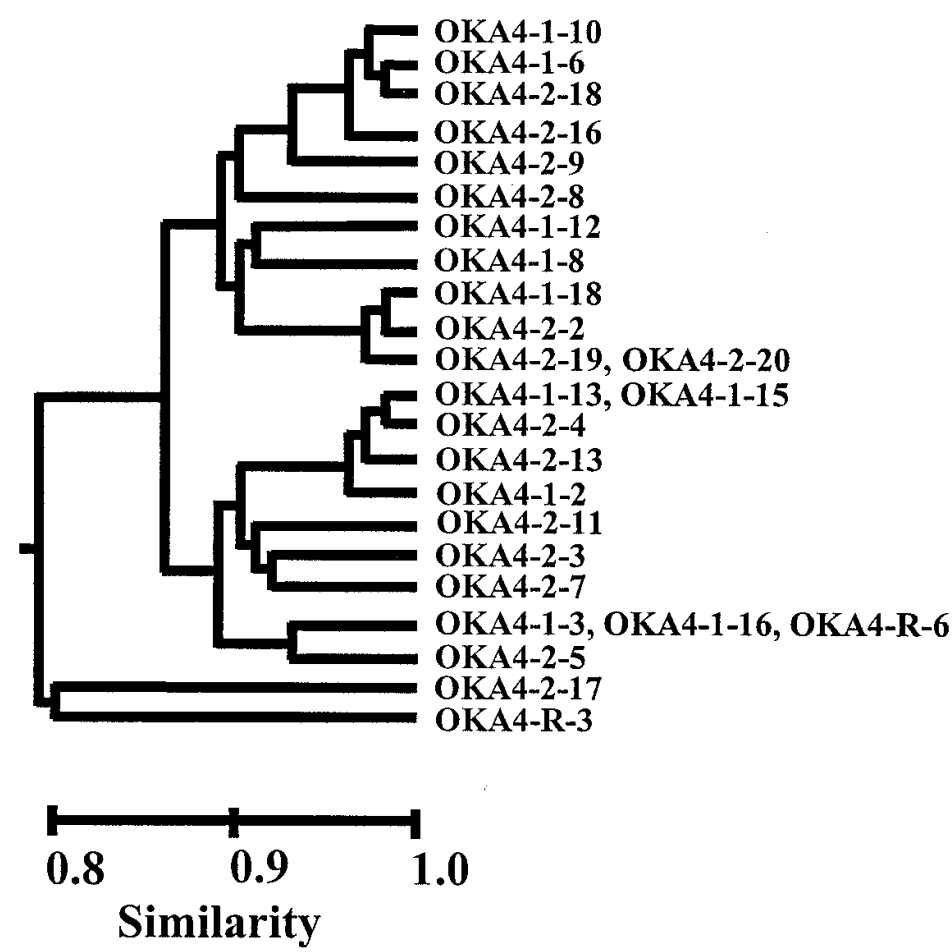

Fig. 1. Estimates of genetic similarity among 26 Ophiosphaerella herpotricha isolates collected from the fourth fairway at Afton, Oklahoma (OK), based on amplified fragment length polymorphisms using the selective primer pair EAA/MCA. Bootstrap values (2,000 replicates) for branch nodes ranged from 3.8 to $42 \%$ (average $=21 \%$ ).

Table 1. Abundance of Ophiosphaerella herpotricha, $O$. korrae, and $O$. narmari isolates associated with spring dead spot patches systematically sampled at three golf courses

\begin{tabular}{|c|c|c|c|c|c|c|}
\hline \multirow[b]{2}{*}{ Golf course, city, state } & \multirow[b]{2}{*}{ Collection date } & \multirow[b]{2}{*}{ Fairway number } & \multirow{2}{*}{$\begin{array}{l}\text { Number of turf } \\
\text { cores collected }\end{array}$} & \multicolumn{3}{|c|}{ Number of isolates $^{a}$} \\
\hline & & & & Oh & Ok & On \\
\hline Shangri-La Resort, Afton, OK & 1994 & 4 & 50 & 34 & 0 & 0 \\
\hline Shangri-La Resort, Afton, OK & 1994 & 11 & 70 & 52 & 3 & 2 \\
\hline Shangri-La Resort, Afton, OK & 1994 & 16 & 70 & 50 & 1 & 2 \\
\hline Shangri-La Resort, Afton, OK & 1996 & 11 & 100 & 34 & 23 & 5 \\
\hline Shangri-La Resort, Afton, OK & 1996 & 16 & 100 & 31 & 11 & 12 \\
\hline South Lakes G.C., Jenks, OK & 1994 & 9 & 50 & 44 & 0 & 0 \\
\hline South Lakes G.C., Jenks, OK & 1994 & 14 & 70 & 64 & 0 & 0 \\
\hline South Lakes G.C., Jenks, OK & 1994 & 16 & 70 & 65 & 0 & 0 \\
\hline Independence C.C., Independence, KS & 1994 & 13 & 70 & 48 & 0 & 0 \\
\hline Independence C.C., Independence, KS & 1994 & 14 & 70 & 23 & 9 & 0 \\
\hline Total cores & & & 720 & & & \\
\hline Total isolates & & & & 445 & 47 & 21 \\
\hline
\end{tabular}

${ }^{\text {a }}$ Based on the number of Ophiosphaerella herpotricha $(\mathrm{Oh}), O$. korrae $(\mathrm{Ok})$, and $O$. narmari $(\mathrm{On})$ isolates recovered from turfgrass cores sampled from each golf course fairway in 1994 and 1996, respectively. Ophiosphaerella spp. were positively identified with species-specific polymerase chain reaction primers. 
PCR preamplification of the ligated template DNA was performed as described in the AFLP Analysis System II instructions, with the exception that the preamplification PCR primers were as follows: EcoRI core plus adapter 5'-CTCGTAGACTGCGTACCAATTC- $3^{\prime}$ and MseI core plus adapter 5'-GACGATGAGTCCTGAGTAA-3'. Individual preamplification PCR reactions consisted of the following: 51- $\mu$ l solution $(46 \mu \mathrm{l}$ from a stock mix of reagents and $5 \mu \mathrm{l}$ of diluted ligated template DNA); $1.3 \mu \mathrm{l}$ each of EcoRI and MseI core plus adapter primers (50 ng/ $\mu \mathrm{l}) ; 0.41-\mu \mathrm{l}$ solution of $100 \mathrm{mM}$ each dATP, dCTP, dGTP, and dTTP; $5.1 \mu \mathrm{l}$ of $10 \times$ PCR buffer (200 mM Tris, $\mathrm{pH} 8.41 ; 500 \mathrm{mM}$ $\mathrm{KCl}$; and $15 \mathrm{mM} \mathrm{MgCl}_{2}$ ); and $0.2 \mu \mathrm{l}$ of Amplitaq DNA polymerase $(5 \mathrm{U} / \mu \mathrm{l})(\mathrm{PE}$ Applied Biosytems, Branchburg, NJ). The reaction mixture was overlaid with $50 \mu \mathrm{l}$ of mineral oil. The following thermal cycler temperature regime was employed: 20 cycles of $94^{\circ} \mathrm{C}$ for $30 \mathrm{~s}$, $56^{\circ} \mathrm{C}$ for $60 \mathrm{~s}$, and $72^{\circ} \mathrm{C}$ for $60 \mathrm{~s}$. Following preamplification, $3 \mu \mathrm{l}$ of the reaction was diluted with $147 \mu \mathrm{l}$ of $\mathrm{TE}$ and stored at $-20^{\circ} \mathrm{C}$ until further use.

Selective amplification of the preamplification template DNA was performed as described in the AFLP Analysis System II instructions with the exception that the selective amplification primers were designed as described by Liscum and Oeller (personal communication). The basic EcoRI-primer is 5'-AGACTGCGTACCAATTCxyz-3' and the basic MseI-primer is 5'-GATGAGTCCTGAGTAAxyz-3' where $\mathrm{x}, \mathrm{y}$, and $\mathrm{z}$ represent the selective bases on the $3^{\prime}$ end of the oligonucleotide. Twelve selective AFLP PCR EcoRI/MseI primer pairs were assessed against 10 isolates each of three SDS fungal species including AA/AA, AA/AC, AA/AG, AA/AT, AA/CA, AA/CC, AA/CG, AA/CT, AA/GA, AA/GC, AA/GG, and AA/GT. Selective AFLP PCR reactions were composed as described in the AFLP Analysis System II instructions, except that the total reaction volume was reduced to $10 \mu \mathrm{l}$. The selective EcoRI primer was end labeled with $\left[\gamma^{33} \mathrm{P}\right]$ ATP $($ specific activity $=2,000 \mathrm{Ci} / \mathrm{mmol})(\mathrm{NEN}$

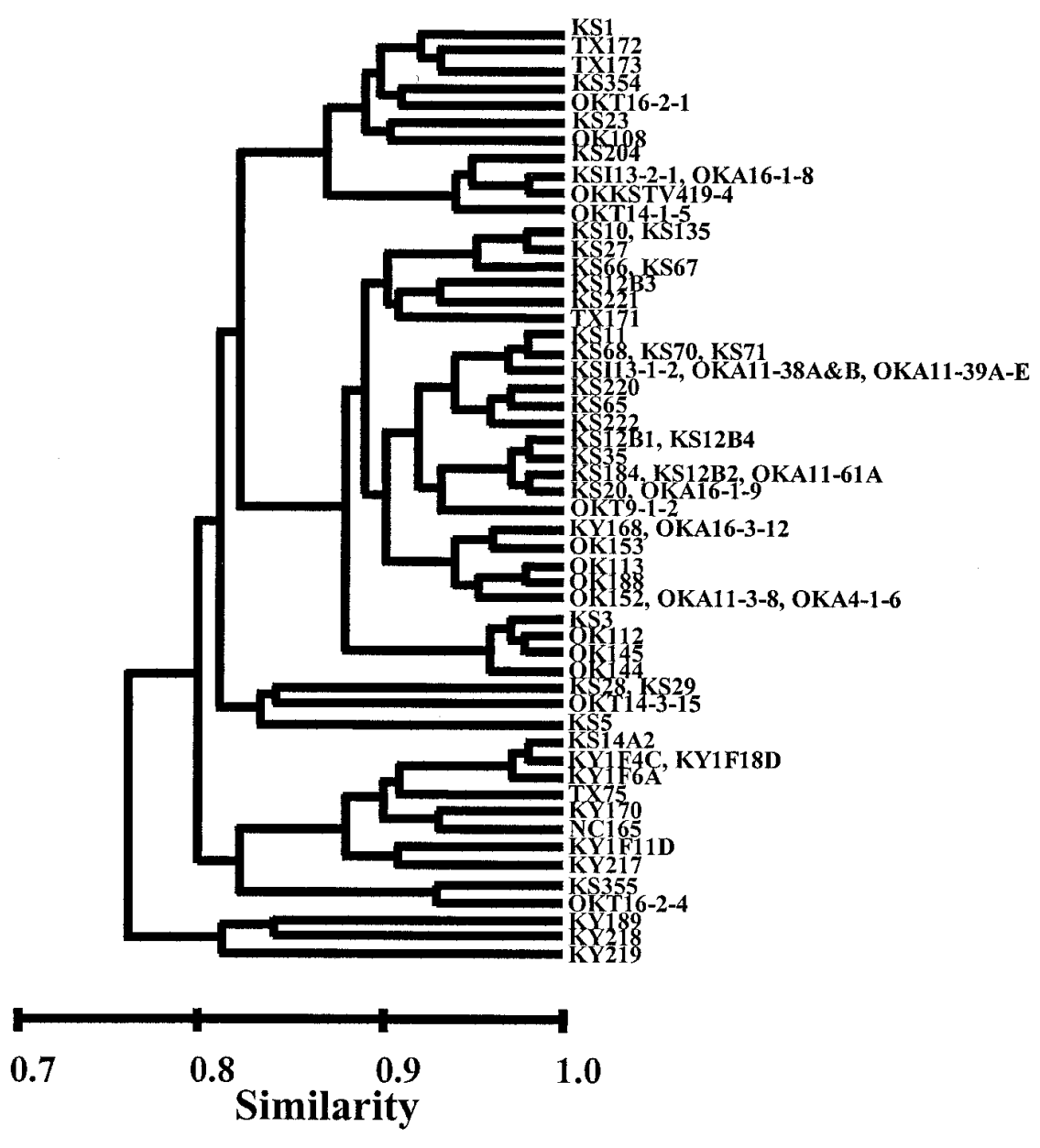

Fig. 2. Estimates of genetic similarity among Ophiosphaerella herpotricha isolates from Kansas (KS), Kentucky (KY), North Carolina (NC), Oklahoma (OK), and Texas (TX) based on amplified fragment length polymorphisms using the selective primer pair EAA/MCA. Isolate KS204 also represents seven additional isolates collected from the sixteenth fairway at Afton, Oklahoma. Isolates from Afton with the letters A to E following the identification number represent cultures collected from the same turf core. Bootstrap values (2,000 replicates) for branch nodes ranged from 0.1 to $58 \%$ (average 19\%).
Life Science Products, Inc., Boston, MA) using T4 polynucleotide kinase supplied with the kit. The reaction mixture was overlaid with $25 \mu \mathrm{l}$ of mineral oil. The following selective AFLP PCR thermal cycler temperature regime was employed: initial cycle of $94^{\circ} \mathrm{C}$ for $30 \mathrm{~s}, 65^{\circ} \mathrm{C}$ for 30 $\mathrm{s}$, and $72^{\circ} \mathrm{C}$ for $60 \mathrm{~s}$ with the following 12 cycles lowering the annealing temperature $0.7^{\circ} \mathrm{C}$ per cycle and the remaining $23 \mathrm{cy}$ cles of $94^{\circ} \mathrm{C}$ for $30 \mathrm{~s}, 56^{\circ} \mathrm{C}$ for $30 \mathrm{~s}$, and $72^{\circ} \mathrm{C}$ for $60 \mathrm{~s}$.

Following the selective AFLP PCR amplifications, reaction DNA was denatured at $90^{\circ} \mathrm{C}$ for $3 \mathrm{~min}$ with an equal vol $(10 \mu \mathrm{l})$ of gel loading buffer (98\% formamide, 10 mM EDTA ( $\mathrm{pH} 8.0), 0.1 \%$ bromophenol blue, and $0.1 \%$ xylene cyanol). Then, 1.7 $\mu \mathrm{l}$ of this mixture was applied to sharkstooth comb-formed wells in a 0.4-mmthick 6\% Long Ranger (FMC BioProducts, Rockland, ME) polyacrylamide gel (38 by $50 \mathrm{~cm})$ resolved at constant power $(100 \mathrm{~W})$ in $1 \times$ TBE running buffer for $2.5 \mathrm{~h}$. Gels were then blotted to $0.33 \mathrm{~mm}$ gel blot paper (Midwest Scientific, Valley Park, MO) and dried using a Bio-Rad Model 583 gel dryer (Bio-Rad Life Science Group, Hercules, CA). Autoradiographs were obtained by exposing Classic BX film (Midwest Scientific, Valley Park, MO) to the dried gel for $72 \mathrm{~h}$ at 22 to $26^{\circ} \mathrm{C}$.

AFLP fragment analysis. DNA bands were scored from AFLP autoradiographs by assigning a number in relation to their migration within the gel. Each gel contained the low mass DNA ladder (Life Technologies) with markers of 2,000, $1,200,800,400,200$, and 100 bp on both sides of the isolates. AFLP bands between 1,300 and $200 \mathrm{bp}$ were scored and included in the analyses. The DNA band with the highest molecular weight was assigned number 1 and so on in ascending order until the band of lowest molecular weight was assigned. It was assumed that bands of the same molecular weight in different isolates were identical. For each isolate, the presence or absence of each band was determined and designated 1 , present, or 0 , absent. AFLP amplification was repeated on six isolates of each fungal species with identical results. The genetic similarity among isolates was estimated using the simple matching coefficient (24) based on the presence or absence data of each band. Calculations on these data were performed using algorithms written in the Interactive Matrix Language (Proc IML) of SAS (version 6, SAS/IML Software: Usage and Reference; SAS/STAT User's Guide, SAS Institute, Inc., Cary, NC). The output of this analysis was written into a genetic similarity matrix. Cluster analysis, using the UPGMA method, was performed on each genetic similarity matrix with the program JMP (version 3.1, SAS), and the clustering among genetically similar isolates was graphically displayed in a dendrogram. To determine the robustness of 
each dendrogram, the presence or absence data were resampled by replacement with 2,000 bootstrap replicates using the program WinBoot (34).

An additional test was performed to determine if the three populations of Ophiosphaerella species exhibited genetic linkage disequilibrium $(D)$ based on locusby-locus comparisons of the AFLP marker data. AFLP markers are dominant and usually have two alleles per locus (15). A $D$ value was calculated using Hill's (8) haploid identification equation (equation 21 , p. 235). A $D$ value not significantly different from zero would support the null hypothesis that the population was in genetic equilibrium, the loci were not linked, and the population did not depart from panmixia. A $D$ value significantly greater than zero was evidence for the presence of disequilibrium, suggesting linkage among loci and a departure from random mating. A chi-square test as described by Zhan et al. (35) was used to test if the $D$ value departure from zero was statistically significant. The chi-square had one degree of freedom based on each locus-by-locus comparison made. Calculations of $D$ and chi-square tests were performed using algorithms written in the Interactive Matrix Language (Proc IML) of SAS.

\section{RESULTS}

Distribution of SDS pathogens. SDS pathogens were isolated from $70 \%$ of all soil cores collected from golf courses in 1994 and 1996 (Table 1). Recovery of Ophiosphaerella spp. from cores collected from individual fairways ranged from 46 to 93\%. O. herpotricha was isolated from each fairway at all three locations and accounted for $87 \%$ of the total number of isolates obtained. At Jenks, O. herpotricha was the only SDS pathogen isolated. $O$. korrae was isolated from cores collected at Afton and Independence, whereas $O$. narmari was detected only in samples from Afton (Table 1).

Although $O$. narmari and $O$. korrae were not as abundant as $O$. herpotricha, they were widely distributed on those fairways where they were detected. The three SDS pathogens were often found within $5 \mathrm{~m}$ of one another, and in nine samples, two Ophiosphaerella species were isolated from different roots in the same turfgrass core.

Genetic diversity in $O$. herpotricha. One hundred and thirty-eight haplotypes (i.e., an isolate or group of isolates with a unique AFLP banding pattern following amplification with the selective primer pair EAA/MCA) of $O$. herpotricha were detected among the 239 isolates collected from 201 turf cores on three different fairways at Afton in 1994 and 1996. Thirtyfive of these haplotypes were represented by at least two, but no more than 15 , isolates. An example of the genotypic variation found at Afton was illustrated from the isolates collected from the fourth fairway (Fig. 1).
Of the 26 isolates analyzed, 22 exhibited different AFLP banding patterns. These haplotypes had genetic similarities ranging from 69 to $98 \%$.

At Afton, isolates of $O$. herpotricha with the same haplotype were often recovered from turf cores collected from SDS patches within a 6-m radius, but identical haplotypes also were found at opposite ends of the same fairway $(>300$ $\mathrm{m})$ and on different fairways. The same haplotype was also isolated at least twice from 27 of the 34 turf cores in which more than one isolate was collected. In two cases, all five isolates from the same turf core were the same haplotype. Conversely, two or three different haplotypes were recovered from 19 of the 34 turf cores in which multiple isolates were collected.

Twenty representative isolates of $O$. herpotricha from the three systematically sampled golf courses were compared with 61 other isolates collected in Kansas, Oklahoma, North Carolina, Kentucky, and Texas (Fig. 2). The genetic similarity among all isolates (range 60 to $98 \%$ ) was similar to that found for isolates collected on the fourth fairway at Afton. Isolates from the same geographic region were generally not tightly clustered, and bootstrap values for most branch nodes in the dendrogram were low (range 0.1 to $58 \%$ ). Five haplotypes were represented by isolates collected in both Kansas and Oklahoma. In one case, an isolate from Kentucky and Oklahoma had the same AFLP banding pattern.

Genetic diversity in $O$. narmari. $O$. narmari isolates were divided into two distinct groups based on AFLP banding patterns (Fig. 3). Isolates from Australia and California exhibited a high degree of genetic similarity even though they were collected from widely diverse geographic regions. Likewise, isolates from Afton and one Kansas isolate were genetically similar. Similar results were observed in AFLP banding patterns among isolates following amplification with another primer pair, EAA/MAG (data not shown).

Nineteen haplotypes were detected among 26 O. narmari isolates collected at Afton. Isolates collected from the same turf core exhibited the same AFLP pattern when amplified with the EAA/MCA and EAA/MAG primer pair combinations in five of the six samples. Two isolates from

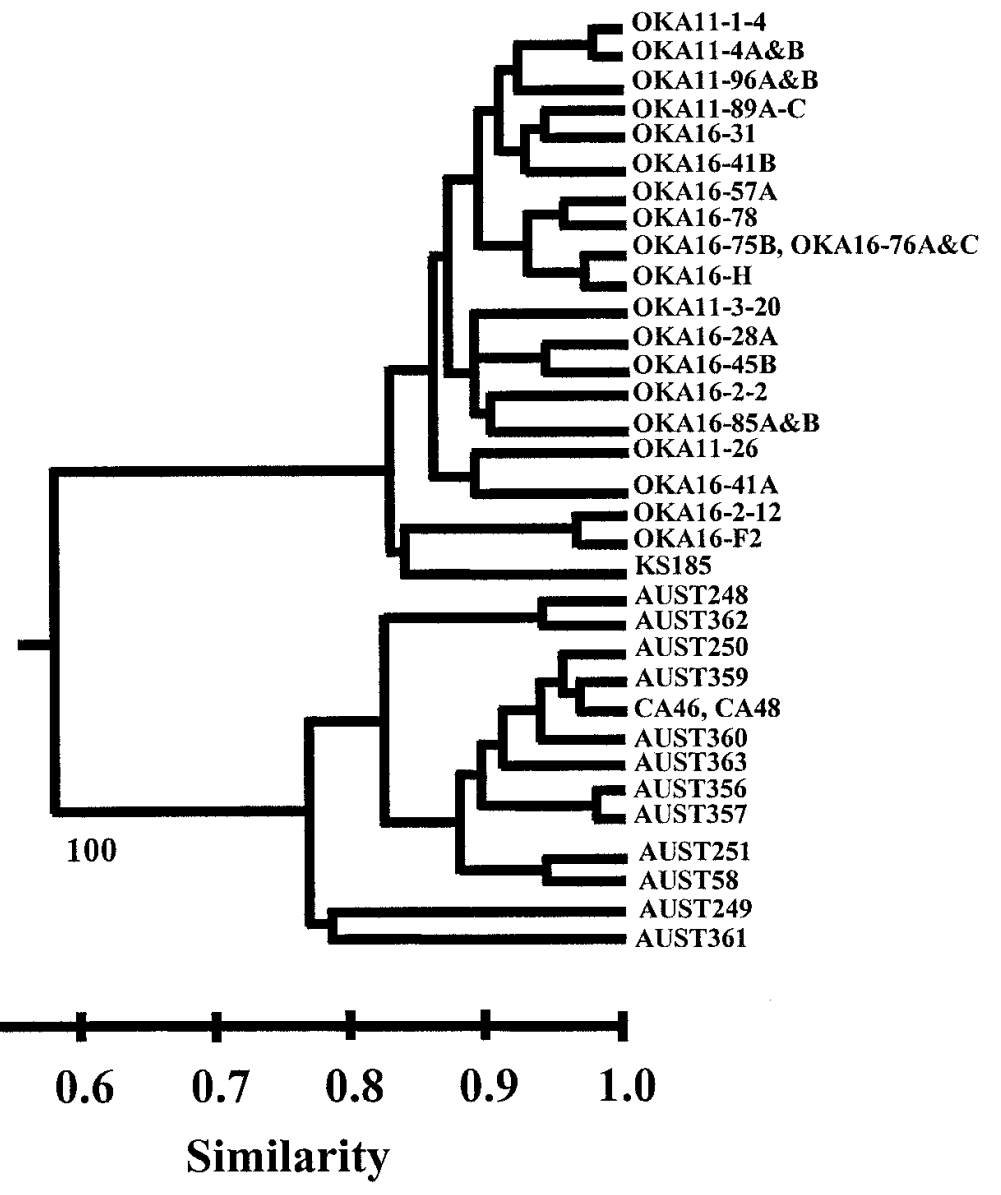

Fig. 3. Estimates of genetic similarity among Ophiosphaerella narmari isolates from California (CA), Oklahoma (OK), and Australia (AUST) based on amplified fragment length polymorphisms using the selective primer pair EAA/MCA. Isolates from Afton, Oklahoma, with the letters A to C following the identification number represent cultures collected from the same turf core. Bootstrap values (2,000 replicates) for branch nodes ranged from 4.1 to $100 \%$ (average $41 \%$ ). 
one turf core differed by 11 and 6 bands for the two primer pair combinations.

Genetic diversity in $\boldsymbol{O}$. korrae. Isolates of $O$. korrae collected over a wide geographic area were clustered into two distinct genetic similarity groups (Fig. 4). Isolates from the southern United States, including those from Arkansas, Georgia, Mississippi, and Tennessee, exhibited a high degree of genetic similarity (average $88 \%$ ), whereas isolates from northern and western regions of North America and from Australia also were very similar (average genetic similarity 91\%). Some of the haplotypes in each group were represented by more than one isolate. These isolates often were collected from widely dispersed geographic regions. For example, OKA163-2 was identical to isolates from nine different locations in the United States. In contrast, genetic similarity between the two groups of isolates was low (average 38\%).

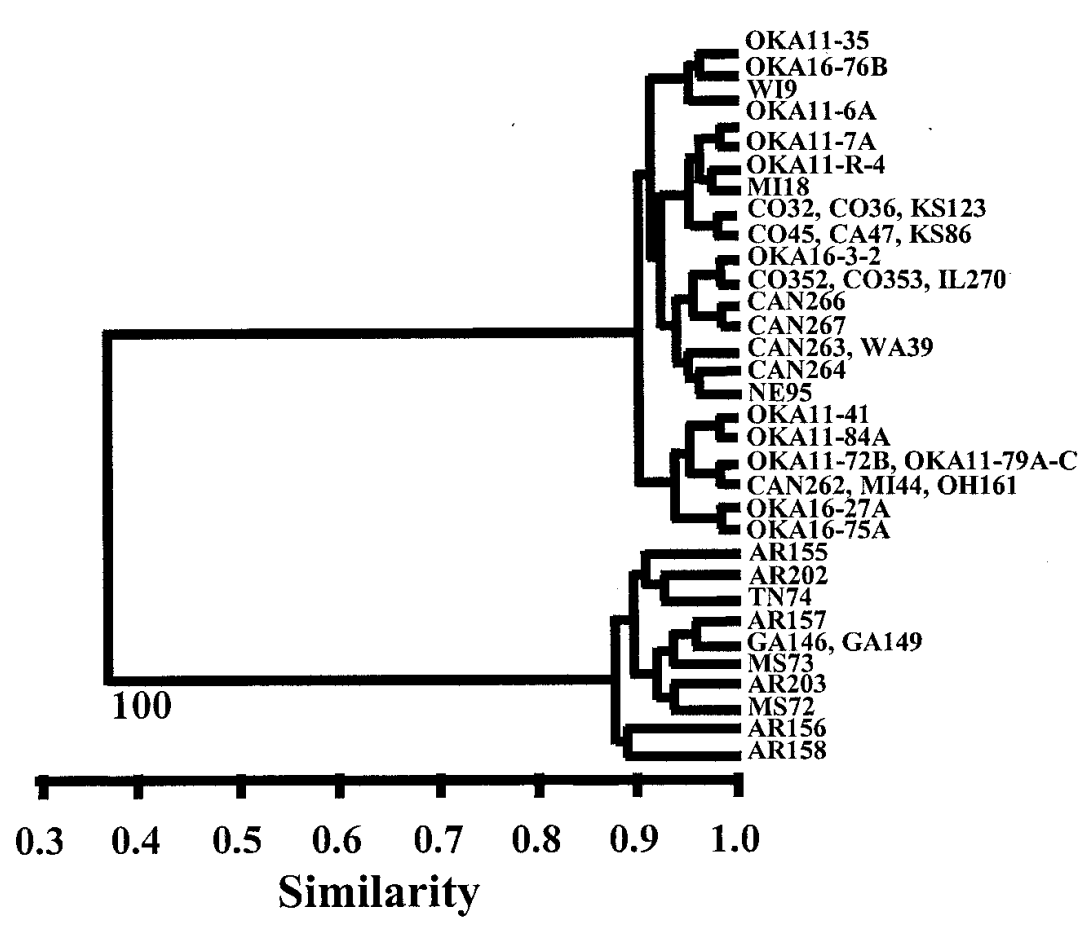

Fig. 4. Estimates of genetic similarity among Ophiosphaerella korrae isolates based on amplified fragment length polymorphisms using the selective primer pair EAA/MCA. Isolate OKA11-84A represents 13 additional isolates from Afton, Oklahoma (OK). Isolate OKA16-3-2 represents 18 additional isolates (eight from Independence, Kansas [KS], one from Colorado [CO], one from Idaho [ID], three from Maryland [MD], one from Michigan [MI], one from Minnesota [MN], one from Ohio $[\mathrm{OH}]$, one from Rhode Island [RD], and one from New Jersey [NJ]). Isolate OKA11-6A represents 42 isolates (41 from Afton and one from Australia [AUST]). Isolate CAN263 represents 13 isolates (two from Canada, two from Washington [WA], six from Idaho, one from New Jersey, one from New York [NY], and one from Pennsylvania). Isolates from Arkansas (AR), Georgia (GA), Illinois (IL), Mississippi (MS), Nebraska (NE), Tennessee (TN), and Wisconsin (WI) also are represented in the dendrogram. Bootstrap values (2,000 replicates) for branch nodes ranged from 0.9 to $100 \%$ (average $27 \%$ ).
There was also a high degree of genetic similarity among isolates collected from different turf cores at Afton (Fig. 4). Only nine haplotypes were detected among the 65 isolates assayed, and 43 of these isolates were the same haplotype. Similarly, multiple isolates collected from the same turf core were identical haplotypes in 15 of these 16 samples.

Genetic linkage disequilibrium $(D)$. A test for genetic linkage disequilibrium $(D)$ was performed on the AFLP fragment data collected from isolates (one isolate of each haplotype) of $O$. herpotricha, $O$. korrae, and $O$. narmari (Table 2). Only $9 \%$ of the $D$ values for $O$. herpotricha were significant, indicating there was only slight linkage disequilibrium. Thirty-seven and 55\% of the $D$ values were significant when all isolates within $O$. narmari and $O$. korrae were compared (Table 2). However, when $O$. narmari and $O$. korrae isolates were first split into their genetic similarity clusters (Figs. 3 and 4) and then analyzed, evidence for linkage disequilibrium was diminished (Table 2). Within the two groups of $O$. narmari, 11 and $5 \%$ of the $D$ values were significant. Within the two groups of $O$. korrae, only $1 \%$ of the $D$ values were significant, suggesting sexual recombination within the groups.

\section{DISCUSSION}

The distribution of SDS pathogens in North America is apparently more complex than previously described (10). Although $O$. herpotricha was the most abundant SDS pathogen isolated in this study, O. korrae also was recovered at two locations. $O$. korrae has been isolated from Kentucky bluegrass with necrotic ring spot disease in Kansas (N. A. Tisserat, unpublished data), but this is the first report of this pathogen on bermudagrass in this region. $O$. narmari, which was previously reported only in Australia and New Zealand $(9,28)$, was isolated from sites in Kansas and Oklahoma. We also determined that the sterile isolates CA46 and CA48 (originally designated as SDS1 and SDS3) collected by

Table 2. Test for genetic linkage disequilibrium $(D)$ within isolate collections of the three Ophiosphaerella spp. using amplified fragment length polymorphisms (AFLP)

\begin{tabular}{|c|c|c|c|c|c|}
\hline Isolates $^{\mathbf{a}}$ & No. of isolates & No. of haplotypes ${ }^{b}$ & $\begin{array}{c}\text { No. of AFLP } \\
\text { markers }\end{array}$ & $\begin{array}{c}\text { Total no. of } \\
\text { comparisons }\end{array}$ & $\underset{(P<0.001)^{\mathrm{c}}}{\% \text { of } D \text { values }}|0|$ \\
\hline Ophiosphaerella herpotricha & 300 & 186 & 45 & 990 & 9 \\
\hline O. narmari & 41 & 33 & 137 & 9,316 & 37 \\
\hline Group A & 14 & 13 & 96 & 4,560 & 11 \\
\hline Group B & 27 & 20 & 90 & 4,005 & 5 \\
\hline O. korrae & 129 & 32 & 44 & 946 & 55 \\
\hline Group A & 118 & 22 & 27 & 351 & 1 \\
\hline Group B & 11 & 10 & 33 & 528 & 1 \\
\hline
\end{tabular}

a Selective primer pair EAA/MCA was used to assess $O$. herpotrich $a$ and $O$. korrae, and the primer pairs EAA/MCA and EAA/MAG were used to assess O. narmari isolates, respectively. O. narmari isolate group A represents individuals from Australia and California, and B represents individuals from Oklahoma and Kansas. O. korrae isolate group A represents individuals from Australia, California, Canada, Colorado, Idaho, Illinois, Kansas, Maryland, Michigan, Minnesota, Nebraska, New Jersey, New York, Ohio, Oklahoma, Pennsylvania, Rhode Island, Washington, and Wisconsin, and B represents individuals from Arkansas, Georgia, Mississippi, and Tennessee.

${ }^{\mathrm{b}}$ Each isolate used in the analysis represents a distinct haplotype, based on its unique AFLP fingerprint.

c Percentage of $D$ values that deviate from absolute zero in that their chi-square value was $\geq 10.83(P<0.001)$ among locus-by-locus comparisons. Each chi-square test was carried out using a single degree of freedom. 
Endo et al. (5) from bermudagrass in California were $O$. narmari. This suggests that $O$. narmari is widely distributed in the United States.

$O$. herpotricha was the most frequently isolated SDS pathogen, and on one golf course, it was the only pathogen isolated during the survey. Whether this is a reflection of the native distribution of SDS pathogens, their differential immigration on roots and stolons during bermudagrass establishment, a reproductive or fitness advantage of $O$. herpotricha on bermudagrass, or a combination of these factors is not known. $O$. herpotricha has been reported from a number of plants in the Poaceae, whereas $O$. korrae and $O$. narmari have a more limited host range $(20,21,27,28)$. A relatively large native population of $O$. herpotricha might explain its higher frequency on bermudagrass. Alternatively, the distribution and frequency of SDS pathogens at a given location may be a function of their abundance in the original bermudagrass source. Most bermudagrass fairways in Kansas and northern Oklahoma are established from vegetatively propagated roots or stolons of cultivars grown in sod farms. Movement of SDS pathogens on colonized stolons previously has been demonstrated (17). Multiple introductions of bermudagrass cultivars, possibly from different farms and infected with different SDS pathogens, could have resulted in the pathogen mixture observed at the Afton golf course. Systematic sampling in other regions of the United States and from bermudagrass sod farms might elucidate the origin and distribution of SDS pathogens.

The presence of more than one SDS pathogen at a given location was reported in Australia (22). However, this is the first report of all three pathogens at the same location. Since multiple isolates were collected from only a small percentage of the turf cores, the frequency of two SDS pathogens present in individual patches may actually be higher. The association and interaction of these pathogens during root colonization and symptom development requires further study.

A relatively large number of genotypes was detected among $O$. herpotrich $a$ and $O$. narmari, but not among $O$. korrae isolates collected at Afton. A high level of genotypic diversity in a fungal population suggests that sexual recombination may be occurring (15). Pseudothecia of $O$. korrae and $O$. narmari were reported to be occasionally present on infected bermudagrass in Australia $(23,28)$, whereas ascocarps of $O$. herpotricha were detected in inoculated bermudagrass in the greenhouse (26). Ascocarps also can be induced in some isolates of $O$. korrae $(2,3)$. Although we have not observed ascocarps of these SDS pathogens in turf samples collected in Kansas or Oklahoma, they might be overlooked since they tend to form on decaying stolons in the thatch layer. While Ophiosphaerella spp. are homothallic, the relatively large number of genotypes and the lack of genetic disequilibrium, particularly within genetic similarity groups (Table 2), suggests that some sexual recombination is occurring. Sexual recombination through outcrossing has been demonstrated in homothallic fungi such as Aspergillus nidulans (18) and Gibberella zeae (1). Nevertheless, Raffle and Hsiang (19) reported no genetic variation among 10 ascospore progeny of one $O$. korrae isolate with RAPD analysis, and they suggested that methods of recombination such as parasexuality or mutations were responsible for generating different haplotypes in this fungus. However, their sampling size was likely too small to detect outcrossing. Further studies are needed to ascertain the mechanisms of genetic diversity in Ophiosphaerella species.

The relatively large number of isolates with identical haplotypes in each Ophiosphaerella species also indicates that asexual propagation of genotypes is occurring. It is unlikely this is a result of asexual spores, since no anamorph has been reported for $O$. narmari or $O$. korrae. An anamorph was described for $O$. herpotricha (29), but we have never observed it in the field or in the hundreds of diseased turf cores or cultures processed. Clonal propagation may have occurred via dispersion of ascospores resulting from inbreeding or by movement of persistent mycelium on bermudagrass roots and stolons. Bermudagrass roots or stolons with ectotrophic hyphae could easily be moved locally by machinery such as mowers and soil aerators. The discovery of the same haplotype of $O$. herpotricha in different regions in different states suggests that haplotypes may be dispersed over large geographic areas, possibly during bermudagrass establishment. Similarly, the presence of identical haplotypes of $O$. korrae in Oklahoma and Australia and the confirmation of $O$. narmari isolates with nearly identical haplotypes from Australia and California strongly suggest that transcontinental movement of these species can occur. Raffle and Hsiang (19) reported the presence of two unique $O$. korrae haplotypes following RAPD analysis. One haplotype was collected in British Columbia and Quebec, Canada, and in the state of Washington, and the other was collected in Ontario, Canada, and Washington. Continental or panglobal distributions of clones or single clonal lineages for other fungal pathogens have also been documented $(6,11)$.

The level of genetic diversity among $O$. herpotricha isolates collected throughout the United States was similar to that found among isolates collected on an individual fairway at Afton. There was no evidence that isolates from a given location (e.g., Afton) were genetically more similar to one another than to isolates from other regions. The probable immigration of isolates on bermudagrass stolons coupled with recombination, presumably from meiotic division, would tend to have a homogenizing effect on genetic diversity. This pattern of high genotypic diversity with low levels of genetic differentiation among geographical locations is similar to that described in Microdochium nivale (13).

The genotypic diversity in $O$. korrae was markedly different from that in $O$. herpotricha. The population at Afton was dominated by just a few haplotypes, and these were nearly identical to isolates collected throughout western and northern North America and Australia (one isolate only). Some of the isolates in this group were originally isolated from bermudagrass, while others were collected from Kentucky bluegrass, indicating that genetic similarity was not necessarily host-related. Several haplotypes were also represented by isolates collected over a wide geographic area. These results are consistent with Raffle and Hsiang (19), who, by using RAPD analysis, found only six haplotypes of $O$. korrae among 71 isolates collected from Kentucky bluegrass in North America. They speculated that the low level of genetic diversity in $O$. korrae was a result of the introduction to the continent of a limited number of genotypes on their major hosts (presumably Kentucky bluegrass and bermudagrass), followed by their distribution over a wide geographic area by asexual propagation. The low level of genetic diversity we found within groups of North American isolates supports this hypothesis.

\section{ACKNOWLEDGMENTS}

We thank Percy Wong for supplying additional O. narmari isolates from Australia and Kevin McCann for helping collect isolates from Oklahoma. This research was sponsored in part by the GCSAA Foundation's Chapter Cooperative Research Program, Heart of America Golf Course Superintendents Association, Kansas Golf Course Superintendents Association, Kansas Turfgrass Foundation, and the United States Golf Association.

\section{LITERATURE CITED}

1. Bowden, R. L., and Leslie, J. F. 1999. Sexual recombination in Gibberella zeae. Phytopathology 89:182-188.

2. Chastagner, G. A, and Hammer, W. 1997. Factors affecting the in vitro production of pseudothecia of Leptosphaeria korrae. Int. Turfgrass Soc. Res. J. 8:847-861.

3. Crahay, J. N., Dernoeden, P. H., and O'Neill, N. R. 1988. Growth and pathogenicity of Leptosphaeria korrae in bermudagrass. Plant Dis. 72:945-949.

4. Dernoeden, P. H., Zhang, M., and Wetzel, H. C. 1995. First report of necrotic ring spot (Leptosphaeria korrae) in creeping red fescue in Maryland. Plant Dis. 79:966.

5. Endo, R. M., Ohr, H. D., and Krausman, E. M. 1985. Leptosphaeria korrae, a cause of the spring dead spot disease of bermudagrass in California. Plant Dis. 69:235-237.

6. Goodwin, S. B., Cohen, B. A., and Fry, W. E. 1994. Panglobal distribution of a single clonal 
lineage of the Irish potato famine fungus. Proc. Natl. Acad. Sci. USA 91:11591-11595.

7. Hawkes, N. J. 1987. Spring dead spot of 'Tifdwarf' turf in South Australia. J. Sports Turf Res. Inst. 63:136-140.

8. Hill, W. G. 1974. Estimation of linkage disequilibrium in randomly mating populations. Heredity 33:229-239.

9. Jackson, N. 1987. Some patch diseases of turfgrasses associated with root and crown infecting fungi. N.Z. J. Turf Manage. 1:21-23.

10. Jackson, N. 1993. Geographic distribution, host range, and symptomology of patch disease caused by soilborne ectotrophic fungi. Pages 17-39 in: Turfgrass Patch Diseases Caused by Ectotrophic Root-Infecting Fungi. B. B. Clarke and A. B. Gould, eds. American Phytopathological Society, St. Paul, MN

11. Kohli, Y., Morrall, R. A. A., Anderson, J. B., and Kohn, L. M. 1992. Local and trans-Canadian clonal distribution of Sclerotinia sclerotiorum on canola. Phytopathology 82:875880.

12. Landschoot, P. J. 1996. First report of necrotic ring spot on Poa annua putting greens in Pennsylvania. Plant Dis. 80:712.

13. Mahuku, G. S., Hsiang, T., and Yang, L. 1998. Genetic diversity of Microdochium nivale isolates from turfgrass. Mycol. Res. 102:559567.

14. McCann, K. M., Tisserat, N. A., and Hulbert, S. H. 1994. Genotypic diversity of Ophiosphaerella herpotricha. (Abstr.) Phytopathology 84:1086.

15. McDonald, B. A. 1997. The population genetics of fungi: Tools and techniques. Phytopathology 87:448-453.

16. O'Gorman, D., Xue, B., Hsiang, T., and Goodwin, P. H. 1994. Detection of Leptosphaeria korrae with polymerase chain reaction and primers from the ribosomal internal transcribed spacers. Can. J. Bot. 72:342-346.

17. Pair, J. C., Crowe, F. J., and Willis, W. G 1986. Transmission of spring dead spot disease of bermudagrass by turf/soil cores. Plant Dis. 70:877-878.

18. Pontecorvo, G., Roper, J. A., Hemmons, L. M., MacDonald, K. D., and Bufton, A. W. J. 1953. The genetics of Aspergillus nidulans. Adv. Genet. 5:141-238.

19. Raffle, V. L., and Hsiang, T. 1998. Low level of DNA polymorphisms in isolates of Leptosphaeria korrae pathogenic on Poa pratensis. Can. J. Plant Pathol. 20:48-54.

20. Shoemaker, R. A. 1976. Canadian and some extralimital Ophiobolus species. Can. J. Bot. 54:2365-2404.

21. Shoemaker, R. A., and Babcock, C. E. 1989. Phaeosphaeria. Can. J. Bot. 67:1500-1599.

22. Smith, A. M. 1967. Spring dead spot of couch grass turf in New South Wales. M.Sc.Agr. thesis. University of Sydney, Sydney, Aust.

23. Smith, A. M. 1971. Spring dead spot of couch grass turf in New South Wales. J. Sports Turf Res. Ins. 47:54-59.

24. Sokal, R. R., and Michener, C. D. 1958. A statistical method for evaluating systematic relationships. Univ. Kans. Sci. Bull. 38:14091438.

25. Tisserat, N. A., Hulbert, S. H., and Sauer, K. M. 1994. Selective amplification of rDNA internal transcribed spacer regions to detect Ophiosphaerella korrae and O. herpotricha. Phytopathology 84:478-482.

26. Tisserat, N. A., Pair, J. C., and Nus, A. 1989. Ophiosphaerella herpotricha, a cause of spring dead spot of bermudagrass in Kansas. Plant Dis. 73:933-937.

27. Walker, J. 1980. Gaeumannomyces, Linocarpon, Ophiobolus, and several other genera of scolecospored Ascomycetes and Phialophora conidial states, with a note on hyphopodia.
Mycotaxon 11:1-129.

28. Walker, J., and Smith, A. M. 1972. Leptosphaeria narmari and $L$. korrae spp. nov., two long-spored pathogens of grasses in Australia. Trans. Br. Mycol. Soc. 58:459-466.

29. Webster, J., and Hudson, H. J. 1957. Graminicolous Pyrenomycetes VI. Conidia of Ophiobolus herpotrichus, Leptosphaeria luctuosa, L. fuckelii, L. pontiformis, and $L$. eustomoides. Trans. Br. Mycol. Soc. 40:509 522.

30. Wetzel, H C. III, Dernoeden, $\mathrm{P}, \mathrm{H}$, and Millner, P. D. 1996. Identification of darkly pigmented fungi associated with turfgrass roots by mycelial characteristics and RAPDPCR. Plant Dis. 80:359-364.

31. Wetzel, H. C., III, Hulbert, S. H., and Tisserat, N. A. 1998. Geographic distribution and genetic diversity of three Ophiosphaerella species that cause spring dead spot of bermudagrass. (Abstr.) Phytopathology 88:S96.

32. Wetzel, H. C., III, Hulbert, S. H., and Tisserat, N. A. 1999. Molecular evidence for the presence of Ophiosphaerella narmari $\mathrm{n}$. comb., a cause of spring dead spot of Bermuda grass, in North America. Mycol. Res. 103:981-989.

33. Worf, G. L., and Stewart, J. S. 1986. Necrotic ring spot disease of turfgrass in Wisconsin. Plant Dis. 70:453-458.

34. Yap, I. V., and Nelson, R. J. 1996. WinBoot: A program for performing bootstrap analysis of binary data to determine the confidence limits of UPGMA-based dendrograms. IRRI Discussion Paper Series 14. International Rice Research Institute, Manila, Philippines.

35. Zhan, J., Mundt, C. C., and McDonald, B. A 1998. Measuring immigration and sexual reproduction in field populations of $\mathrm{Myco}$ sphaerella graminicola. Phytopathology 88: 1330-1337. 